\title{
Phosphorus Removal and Recovery from High Phosphorus Wastewater by the HAP Crystallization Process
}

\author{
YU MENGLIN ${ }^{1}$, YIN DANYANG $^{2}$, SHI JING ${ }^{1 *}$, \\ SONG DUANMEI ${ }^{1}$ and XU ZHENGWEN ${ }^{2}$
}

\author{
'School of Engineering, China Pharmaceutical University, China. \\ ${ }^{2}$ Department of Environmental Science and Engineering, \\ Nanjing Universityof Information Science and Technology, China. \\ *Corresponding author E-mail: shijing_cpu@ 163.com
}

http://dx.doi.org/10.13005/ojc/320125

(Received: February 01, 2016; Accepted: March 09, 2016)

\begin{abstract}
In the experiment, the crystallization process was compared with the chemical precipitate process for phosphorus removal efficiency. Calcites were used as seeds to remove and recover phosphorus from synthetic phosphorite wastewater. The results indicated that under the same wastewater compositions, the crystallization process showed better phosphorus removal performance. At the initial stage, the corresponding removed $\mathrm{Ca} / \mathrm{P}$ ratio (DCa/DP) was 1.43:1. When the phosphorus concentration was low, phosphorus could be removed further in the crystallization system, whereas the chemical precipitation stopped. During the reaction, calcium concentration firstly decreased because of precipitation or crystallization. Then it slightly increased, which possibly resulted from the transformation of HAP precursor or the dissolution of calcite seeds. The effects of $\mathrm{pH}$, initial phosphorus concentration and $\mathrm{Ca} / \mathrm{P}$ ratio were investigated. Phosphorus removal and recovery efficiency increased with the increment of the above three factors. In addition, the Response Surface Methodology was used to optimize the related factors. A significant quadratic model was obtained. From the optimization results, it could be found that when $\mathrm{pH}$ value was 9.0 , molar ratio was 1.07 and reaction time was $36 \mathrm{~h}$, the phosphorus removal rate could reach $96.1 \%$.
\end{abstract}

Key words: calcite, hydroxyapatite, phosphorus recovery, phosphorus wastewater.

\section{INTRODUCTION}

Phosphorus is one of the limiting elements for eutrophication ${ }^{1}$. An excessive discharged phosphorus in water bodies leads to algal blooms, resulting in the reduction of available oxygen and the deterioration of the water quality ${ }^{2}$. The amounts of phosphorus in some types of wastewater are considerable, such as industrial wastewater ${ }^{3}$, swine wastewater ${ }^{4}$, agricultural wastewater ${ }^{5}$, pharmaceutical wastewater ${ }^{6}$ and phosphorite wastewater ${ }^{7-8}$.

On the other hand, phosphorus is a nonrenewable resource and becoming rarer. And it has no substitute in the nature ${ }^{9}$. However the demand for phosphate rock is continually growing. According to the statistics from United States 
Geological Survey, the phosphorus rock production in 2009 around the world was 166 million tons, which were 181 million tons in 2010 and 198 million tons in 2011 10-12. Consequently, much attention has been paid to phosphorus recovery from wastewater to realize the sustainable utilization of phosphorus. Struvite (MAP, $\mathrm{MgNH}_{4} \mathrm{PO}_{4}$ ) and hydroxyapatite (HAP, $\left.\mathrm{Ca}_{5}\left(\mathrm{PO}_{4}\right)_{3} \mathrm{OH}\right)$ crystallization processes are the main methods. In the above process, crystals of MAP or HAP are formed by the following reactions.

$\mathrm{Mg}^{2+}+\mathrm{PO}_{4}^{3-}+\mathrm{NH}_{4}^{+}+6 \mathrm{H}_{2} \mathrm{O} \rightarrow \mathrm{MgNH}_{4} \mathrm{PO}_{4} \cdot 6 \mathrm{H}_{2} \mathrm{O}$

$10 \mathrm{Ca}^{2+}+6 \mathrm{PO}_{4}^{3-}+2 \mathrm{OH}^{-} \rightarrow \mathrm{Ca}_{10}\left(\mathrm{PO}_{4}\right)_{6}(\mathrm{OH})_{2}$

By the above methods, some researchers have recycled phosphorus from various kinds of wastewaters, using different materials as seeds. Chen utilized xonotlite as the seed to recover phosphorus from the supernatant of concentrated sludge. The removal efficiency reached $91.3 \%$ after $24 \mathrm{~h}$ reaction ${ }^{13}$. Powdered converter slag was used as a seed material to recover phosphorus in the membrane-filtrate wastewater by Eung-Ho Kim ${ }^{14}$. High concentration of phosphorus was deposited on the surfaces of seed particles in the form of HAP. In this study, calcites were used as the seeds to remove and recover phosphorus from synthetic phosphorite wastewater.

As stated above, the phosphorus concentration in phosphorite wastewater is high. In order to recover phosphorus, in this experiment

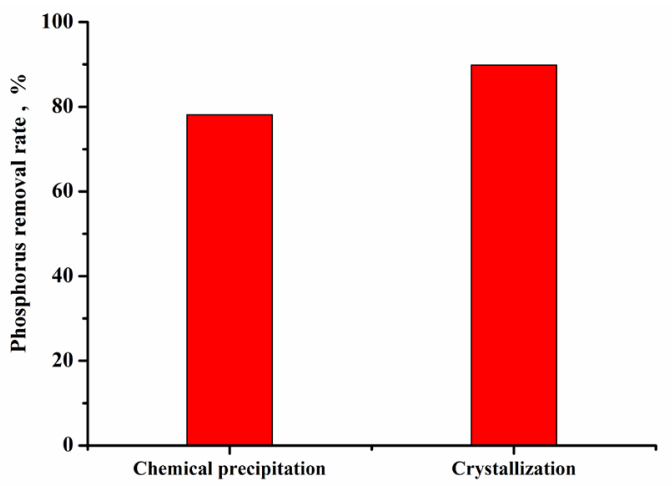

Fig.1: Phosphorus removal rates in crystallization and chemical precipitation systems after 72 chemical precipitate process was compared with crystallization process for the same synthetic phosphorite wastewater. Due to the low ammonia concentration, HAP was considered as the suitable recovery crystallization process. As the main factors, the effect of initial phosphorus concentration, $\mathrm{pH}$ value, molar ratio of calcium and phosphorus and reaction time on the removal efficiency were investigated. Furthermore, Design Expert software was used to optimize the related factors.

\section{MATERIALS AND METHODS}

\section{Synthetic phosphorite wastewater}

The phosphate concentration of the water samples was from 30 to $120 \mathrm{mg} / \mathrm{L}$, and COD was about $100 \mathrm{mg} / \mathrm{L}$. The wastewater was prepared by potassium dihydrogen phosphate $\left(\mathrm{KH}_{2} \mathrm{PO}_{4}\right)$ and acetic acid $\left(\mathrm{CH}_{3} \mathrm{COOH}\right)$. $\mathrm{pH}$ was adjusted with the solution of hydrochloric acid $(\mathrm{HCl})$, sodium hydroxide $(\mathrm{NaOH})$. Calcite was used as the seed.

\section{Experimental procedure}

The experiments were carried out in a constant-temperature air-bathing shaker at 25 ! with the rotational speed $120 \mathrm{r} / \mathrm{min}$. The other parameters were listed in Table 1. The water samples were filtrated by $0.45 \mu \mathrm{m}$ membranes before analysis at different time intervals.

\section{Analytical methods}

$\mathrm{pH}$ was instrumentally measured by Sartorius PB-10 pH meter. Phosphorus was

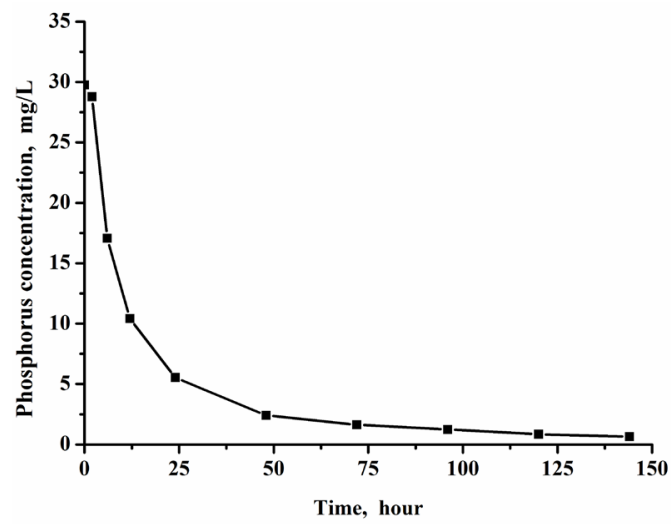

Fig. 2: The variations of phosphorus concentration (the initial phosphorus concentration was $60 \mathrm{mg} / \mathrm{L}, \mathrm{Ca} / \mathrm{P}$ ratio was 0.9 , Seed dosage was $40 \mathrm{~g} / \mathrm{L}$, $\mathrm{pH}$ value was 9) 
determined in accordance with ammonium molybdate spectrophotometric method ${ }^{15}$. And calcium ions were determined by an atomic absorption spectrometry (AAS) spectrometer. TOC was measured via a TOC analyzer (TOC-L-CPH, Shimadzu, Japan). The analyses of Response Surface Methodology (RSM) were used for parameter optimization by Design expert software.

\section{RESULTS AND DISCUSSION}

\section{Comparison of induced crystallization and chemical precipitation}

As shown in Fig.1, compared to chemical precipitation, crystallization obtained better phosphorus removal efficiency. At the initial stage, the two systems showed similar performance. After 6 hours, when the phosphorus concentration in the solution was low, in the crystallization system phosphorus could be removed continuously, whereas the removal was stopped in the precipitation system. The interface energy could be reduced by the calcite seeds, so phosphate and calcium were retained in the form of crystallization on seed surface. Moreover, in comparison with precipitation system, the product achieved by crystallization had less water content, which was easier to be separated and reused as fertilizer ${ }^{16-17}$. It is additional advantage of crystallization.

\section{Variations of calcium and phosphorus in the induced crystallization system}

In the induced crystallization system, the content of soluble phosphate decreased rapidly in $12 \mathrm{~h}$ (Fig.2), declined with the reaction time and tended to a balance. Phosphorus removal efficiency reached almost $100 \%$. The initial phosphorus concentration was $60 \mathrm{mg} / \mathrm{L}$, but after calcium was added the concentration it immediately dropped to $30 \mathrm{mg} / \mathrm{L}$. Inevitably, calcium phosphorus precipitation was formed because of the supersaturation. About $30 \mathrm{mg} / \mathrm{L}$ phosphorus and $58 \mathrm{mg} / \mathrm{L}$ calcium were removed from the solution immediately after mixing, and the corresponding removed $\mathrm{Ca} / \mathrm{P}$ ratio (DCa/DP) was 1.43:1. Consequently, it could be inferred that the possible formation of precipitate was $\mathrm{Ca}_{3}\left(\mathrm{PO}_{4}\right)_{2}$, with the $\mathrm{Ca} / \mathrm{P}$ ratio of 1.5 . When the phosphorus concentration was low, phosphorus could be removed further, which indicated that the induced crystallization could still occur whereas the chemical precipitation was stopped. At the low phosphorus and calcium concentrations, the interfacial energy was reduced by the calcite seed, so the phosphate crystals deposited on the surfaces of calcite. HAP could grow on under metastable state by the seed in the crystallization ${ }^{13}$.

Within $24 \mathrm{~h}$, the average $\mathrm{DCa} / \mathrm{DP}$ ratio was $1: 5$, much less than the $\mathrm{DCa} / \mathrm{DP}$ ratio at the initial stage. In addition, the calcium had a slight increase after $24 \mathrm{~h}$. There were two possible reasons for this phenomenon. Firstly, the main form of calcite seed was calcium carbonate, which could provide calcium ions. Secondly, the precursor of HAP was transformed, making the $\mathrm{Ca} / \mathrm{P}$ ratio change, and consequently partial of the calcium dissolved. The increased calcium ions were beneficial to restrain the phosphorus concentration in the solution.

\section{The effect of $\mathrm{pH}$ on the recovery of phosphorus crystallization}

It could be observed from Fig. 4 that the efficiency of phosphate removal was improved at higher $\mathrm{pH}$ value. Furthermore, as shown in Fig.5, the removal processes was in accordance with pseudosecond-order kinetics equation during $0 \sim 48 \mathrm{~h}$. The

Table 1: The parameters in the experiments

\begin{tabular}{lccc}
\hline Factor & $\begin{array}{c}\text { Phosphorus } \\
\text { concentration } / \mathbf{~ m g}^{\circ} \mathbf{L}^{-1}\end{array}$ & $\mathbf{C a} / \mathbf{P}^{*}$ & $\begin{array}{c}\mathbf{p H} \\
\text { value }\end{array}$ \\
\hline $\mathrm{pH}$ value & 60 & 0.9 & $5,7,9$ \\
$\mathrm{Ca} / \mathrm{P}^{*}$ & 60 & $0.6,0.9,1.2,1,5,1.8$ & 9 \\
Phosphorus & $30,60,90,120$ & 0.9 & 9 \\
concentration & & & \\
\hline
\end{tabular}

*: mole ratio. 
reaction rate constant increased with the increase of $\mathrm{pH}$ values. However, this did not mean that the higher $\mathrm{pH}$ could improve the crystallization quality. When $\mathrm{pH}$ was higher than 9, the bicarbonate ion would transform into carbonate ion, resulting in the calcium carbonate precipitate, mixed with the calcium phosphorus product ${ }^{13}$.

From Fig.6, it could be seen that when the $\mathrm{pH}$ was higher than 7 , the calcium concentration reduced during $0 \sim 24 \mathrm{~h}$, indicating the precipitation or crystallization occurred. But, at $\mathrm{pH} 5$ the calcium increased due to the dissolution of the calcite seeds at weak-acid condition. After $24 \mathrm{~h}$, the concentration of calcium increased slightly with the time. The concentration of TOC in the process of the whole reaction basically remained unchanged, indicating

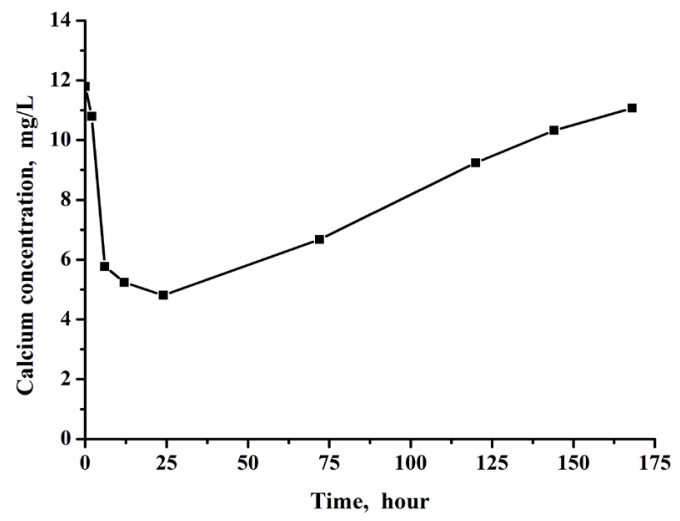

Fig. 3: The variations of calcium concentration (the initial phosphorus concentration was 60 $\mathrm{mg} / \mathrm{L}, \mathrm{Ca} / \mathrm{P}$ ratio was 0.9 , seed dosage was 40 $\mathrm{g} / \mathrm{L}, \mathrm{pH}$ value was 9 )

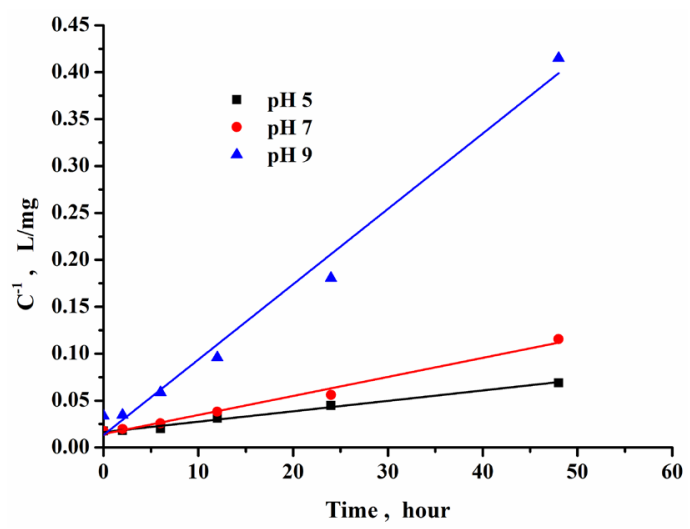

Fig. 5: The fitting of pseudo-second-order kinetics equation that no organic matter was adsorbed on the seed surface, so the presence of organic matter would not affect the crystallization.

\section{Effect of $\mathrm{Ca} / \mathrm{P}$ ratio on the recovery of phosphorus crystallization}

It can be seen from the Fig. 7 that the $\mathrm{Ca} / \mathrm{P}$ ratio had an impact on the recovery of crystallization. When the $\mathrm{Ca} / \mathrm{P}$ ratio was 0.6 , the removal rate of phosphorus was less than $90 \%$ within $96 \mathrm{~h}$, which was significantly lower than the results of other $\mathrm{Ca} / \mathrm{P}$ ratios. Although the better removal rate was achieved at higher $\mathrm{Ca} / \mathrm{P}$ ratio, it was uneconomical to add excessive calcium for recovering phosphorus. High calcium dosage also resulted in the supersaturation, therefore the dominated reaction was calcium phosphorus precipitation, even though

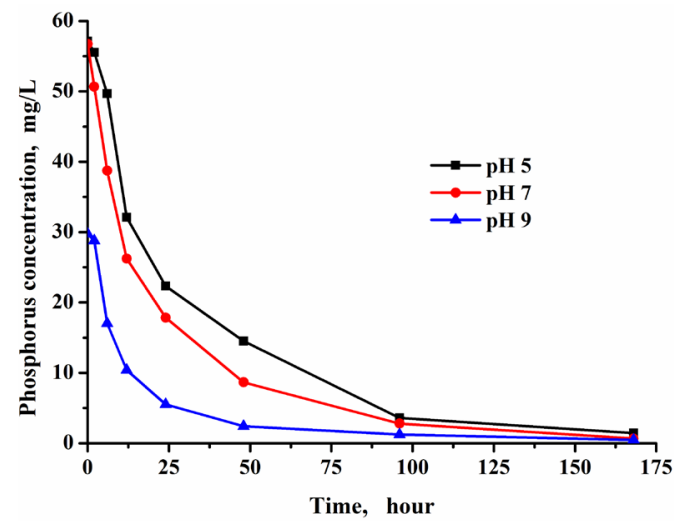

Fig. 4: The variations of phosphorus concentration at different $\mathrm{pH}$ values

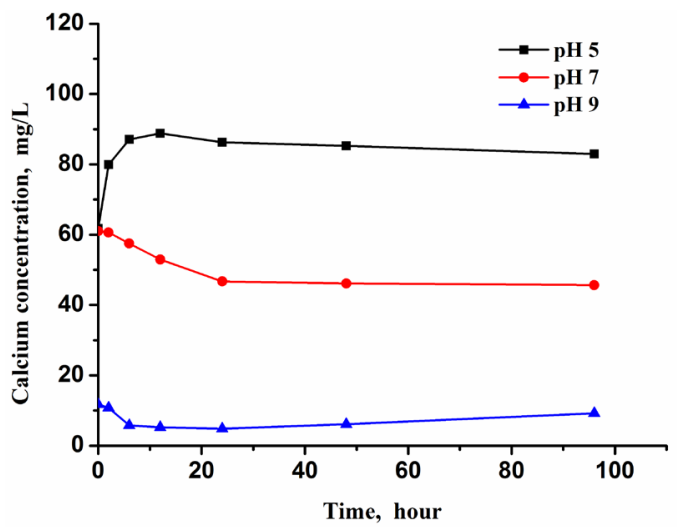

Fig. 6: The variations of calcium concentration at different $\mathrm{pH}$ values 
the phosphorus removal efficiency increased. When the $\mathrm{Ca} / \mathrm{P}$ ratio was 1.8 , phosphorus was removed about $90 \%$ immediately after mixing, demonstrating that chemical precipitation was the main reason for the phosphorus removal. From an economical point of view, it is better to choose 0.9 as the $\mathrm{Ca} / \mathrm{P}$ ratio. When the $\mathrm{Ca} / \mathrm{P}$ ratio was 0.9 , the recovery rate of phosphate can reached $96 \%$ within $48 \mathrm{~h}$.

\section{Effect of initial phosphorus concentration}

It was indicated from the Fig. 8 that under different initial concentrations of phosphorus, the phosphorus decreased rapid in the initial stage and leveled off over $48 \mathrm{~h}$. $\mathrm{pH}$ values also changed during the reaction. Judging from the reaction mechanism, at the initial period, phosphorus was mainly removed with homogeneous precipitate.

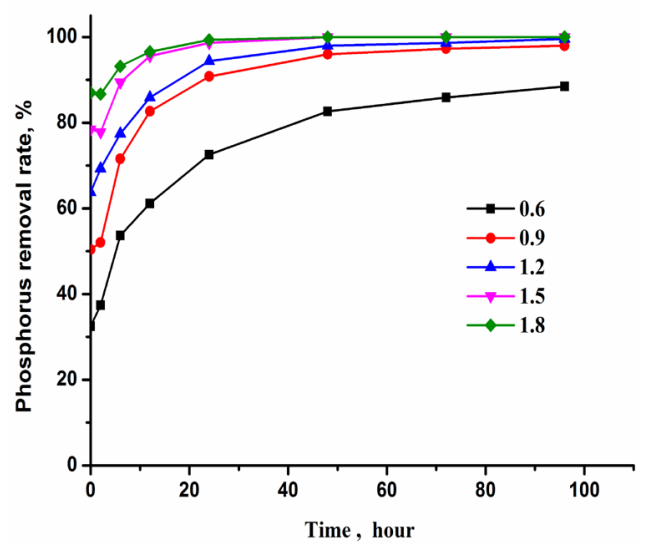

Fig. 7: The variations of phosphorus removal rate at different $\mathrm{Ca} / \mathrm{P}$ ratios

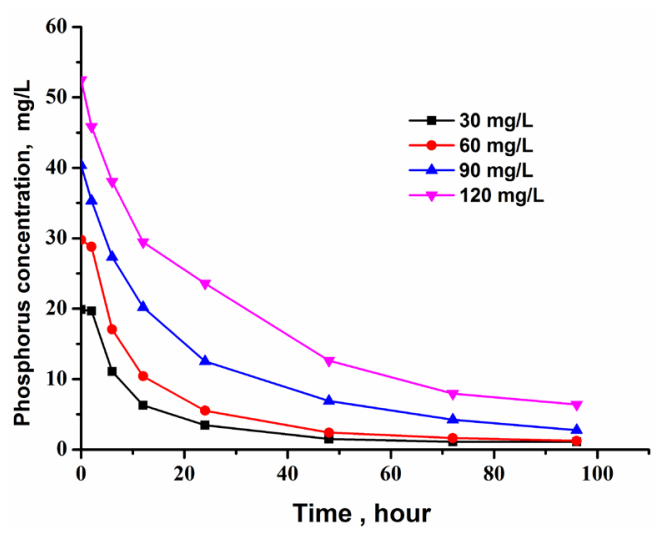

Fig.8: The variations of phosphorus removal rate at different initial phosphorus concentrations
The higher concentration of phosphorus in the solution, the more homogeneous precipitate occurred and the higher phosphorus removal rate was obtained. Then, the $\mathrm{pH}$ value increased, which possibly resulted from the transformation of HAP precursor and calcium carbonate coprecipation. With the decrease of phosphorus concentration, the heterogeneous crystallization dominated gradually. As mentioned before, after $12 \mathrm{~h}$, the concentration of calcium ion slightly increased, probably due to the dissolution from calcite seed. From this point, if more phosphorus wastewater were added, the phosphorus removal could continue.

\section{Optimization by the response surface method}

The process was optimized for the important parameters like $\mathrm{pH}$, time, and $\mathrm{Ca} / \mathrm{P}$ ratio. The removal rate of phosphorus was considered as the foundation to ascertain the best optimized factor which was directed by using Box-Behnken design. Box-Behnken design which belongs to the response surface methodology (RSM) was used in order to demonstrate the nature of the response and to clarify the optimum states of the most important independent variables ${ }^{18}$. Three major variables were time, $\mathrm{pH}$ and $\mathrm{Ca} / \mathrm{P}$ ratio. These factors were tested at three different levels (low, basal, high) as shown in Table 2. According to the Box-Behnken design for three variables, a significant quadratic model ( $P$-value $<0.0001$ ) was obtained by using analysis of variance (ANOVA), which was listed as follows. The phosphorus removal rate $=-283.89255+40.50968$ $(\mathrm{pH})+221.17606(\mathrm{Ca} / \mathrm{P}$ ratio $)+3.69905$ (time) $2.94167(\mathrm{pH}) \times(\mathrm{Ca} / \mathrm{P}$ ratio $)-0.21958(\mathrm{pH}) \times($ time $)$

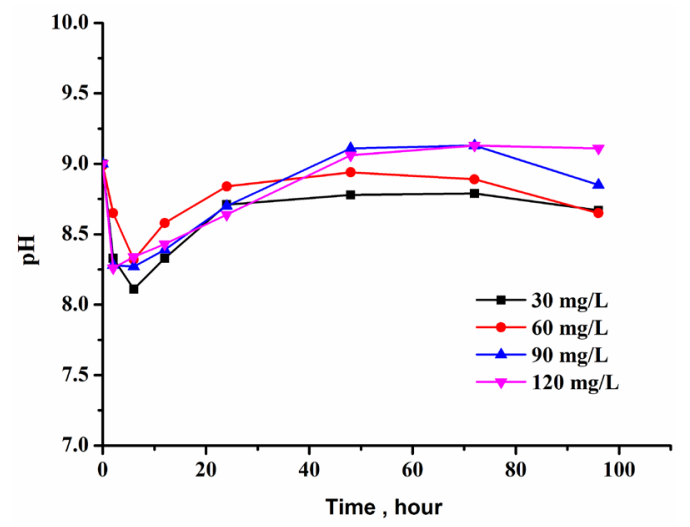

Fig. 9: The variations of $\mathrm{pH}$ at different initial phosphorus concentrations 


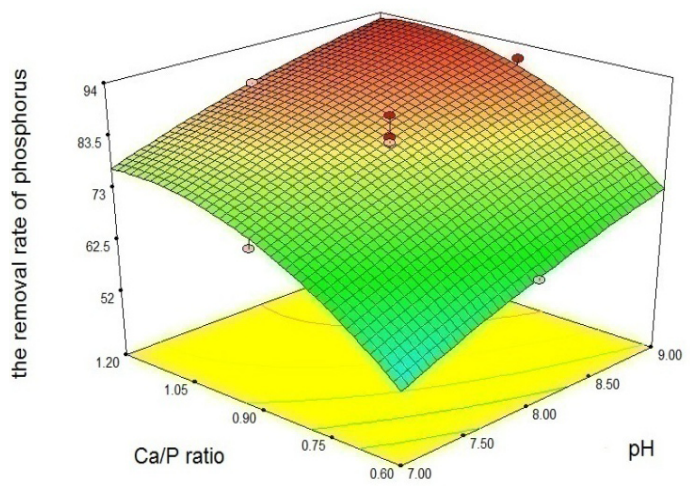

(a) Surface plot of the removal rate of phosphorus (\%) vs $\mathrm{Ca} / \mathrm{P}$ ratio, $\mathrm{pH}$

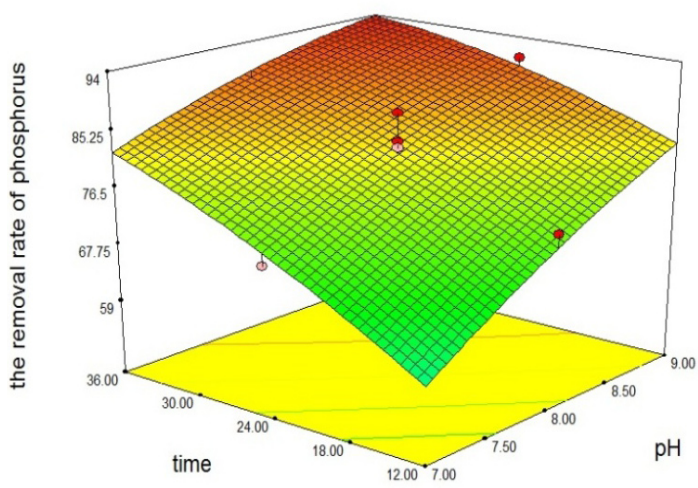

(b) Surface plot of the removal rate of phosphorus (\%) vs time, $\mathrm{pH}$

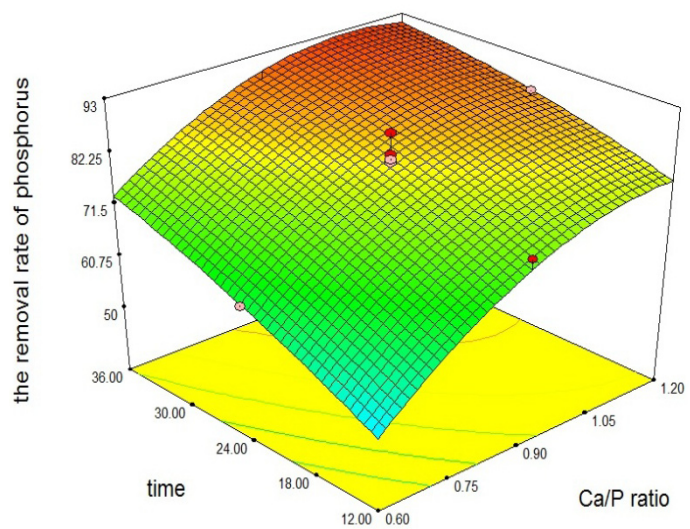

(c) Surface plot of the removal rate of phosphorus (\%) vs time, $\mathrm{Ca} / \mathrm{P}$ ratio

Fig. 10: 3D surface plots of the removal rate of phosphorus as a function: (a)Ca/P ratio and $\mathrm{pH}$, (b) time and $\mathrm{pH}$, (c) time and $\mathrm{Ca} / \mathrm{P}$ ratio.
Table 2: The actual and predicted values of phosphorus removal rates

\begin{tabular}{llllll}
$\begin{array}{l}\text { Standard } \\
\text { order }\end{array}$ & pH & Ca/P & Time & $\begin{array}{c}\text { Actual } \\
\text { Value }\end{array}$ & $\begin{array}{c}\text { Predicted } \\
\text { Value }\end{array}$ \\
\hline 1 & & & & & \\
2 & 7 & 0.6 & 12 & 36.5 & 37.2 \\
3 & 9 & 0.6 & 12 & 61.1 & 61.4 \\
4 & 7 & 1.2 & 12 & 67.2 & 66.7 \\
5 & 9 & 1.2 & 12 & 85.9 & 87.5 \\
6 & 7 & 0.6 & 36 & 67.0 & 65.2 \\
7 & 9 & 0.6 & 36 & 78.6 & 79.0 \\
8 & 7 & 1.2 & 36 & 84.9 & 84.5 \\
9 & 9 & 1.2 & 36 & 95.5 & 94.7 \\
10 & 7 & 0.9 & 24 & 70.3 & 72.2 \\
11 & 9 & 0.9 & 24 & 90.8 & 89.4 \\
12 & 8 & 0.6 & 24 & 63.4 & 63.9 \\
13 & 8 & 1.2 & 24 & 86.4 & 86.5 \\
14 & 8 & 0.9 & 12 & 73.9 & 71.8 \\
15 & 8 & 0.9 & 36 & 86.8 & 89.5 \\
16 & 8 & 0.9 & 24 & 80.8 & 82.3 \\
17 & 8 & 0.9 & 24 & 81.0 & 82.3 \\
18 & 8 & 0.9 & 24 & 87.1 & 82.3 \\
19 & 8 & 0.9 & 24 & 81.8 & 82.3 \\
20 & 8 & 0.9 & 24 & 82.8 & 82.3 \\
\hline & 8 & 0.9 & 24 & 81.8 & 82.3 \\
\hline
\end{tabular}

$-0.71806(\mathrm{Ca} / \mathrm{P}$ ratio $) \times($ time $)-1.49864(\mathrm{pH})^{2}-$

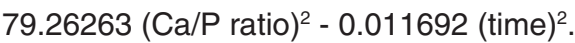

The corresponding analysis of variance (ANOVA) showed the variables that were extremely significant were the square term of $\mathrm{Ca} / \mathrm{P}$ ratio. Furthermore, the linear effect of $\mathrm{pH}$, and $\mathrm{Ca} / \mathrm{P}$ ratio and time were significant at the level of $p$-value 0.001 . The 3D plots for the relation between two variables were illustrated in Fig.10. From the optimization results, when $\mathrm{pH}$ value was $9.00, \mathrm{Ca} / \mathrm{P}$ ratio was 1.07 and reaction time was $36 \mathrm{~h}$, the phosphorus removal rate can reach $96.1 \%$.

\section{CONCLUSION}

In the experiment, the crystallization process was compared with the chemical precipitate process for phosphorus removal efficiency. Under the same wastewater compositions, the crystallization process showed better phosphorus removal performance. During the crystallization reaction, 
calcium concentration firstly decreased because of precipitation or crystallization. Then it slightly increased, which possibly resulted from the transformation of HAP precursor or the dissolution of calcite seeds. Phosphorus removal and recovery efficiency increased with the increment of the $\mathrm{pH}$, initial phosphorus concentration and $\mathrm{Ca} / \mathrm{P}$ ratio. Moreover, a significant quadratic model was obtained by the Response Surface Methodology. The optimization results showed that when $\mathrm{pH}$ value was 9.0 , molar ratio was 1.07 and reaction time was $36 \mathrm{~h}$, the phosphorus removal rate could reach $96.1 \%$.

\section{ACKNOWLEDGEMENT}

This research has been supported by the National Natural Science Foundation of China (51408612), the Natural Science Foundation of Jiangsu Province (BK20140660) and the Fundamental Research Funds for the Central Universities (2015PT002).

\section{REFERENCES}

1. Oladoja, N. A.; Ololade, I. A.; Adesina, A.O.; AdelagunR. O. A.; SaniY. M. Chem. Eng. Res. Des. 2013, 91, 810-818

2. Lürling, M.; Oosterhout, F.V. Water. Res. 2013, 47, 6527-6537

3. Huang, Y H; Shih, Y. J.; Chang, C. C.; Chuang, S. H. Desalin. Water Treat. 2011, 32, 351356

4. Suzuki, K.; TanakaY.; Kuroda, K.; Hanajima, D.; Fukumoto, Y. Bioresour. Technol. 2005, 96, 1544-1550

5. Yi, W. G.; Lo, K. V. J. Environ. Sci. Health., Part B. 2003, 38, 501-509

6. Qiu, G. L.; Song, Y. H.; Zeng, P.; Xiao, S.; Duan, L. Chemosphere. 2011, 84, 241-246

7. Xu, C. W.; Gao, H. L. Environ. Technol. 2004, 4, 25-28

8. Lu, Y. Research on Treatment and Reuse Technic of Phosphorite Processing wastewater. PhD thesis, Wuhan University of Technology, Wuhan, 2010.

9. Shu, L.; Schneider, P.; Jegatheesan, V.; Johnson, J. Bioresour Technol. 2006, 97, 2211-2216

10. U.S. Geological Survey. Mineral Commodity
Summaries 2011. U.S. Government Printing Office, Washington, 2011.

11. U.S. Geological Survey. Mineral Commodity Summaries 2012. U.S. Government Printing Office, Washington, 2012.

12. U.S. Geological Survey. Mineral Commodity Summaries 2013. Washington U.S. Government Printing Office, Washington, 2013.

13. Chen, X. C.; Kong, H. N.; Wu, D. Y.; Wang, X. Z.; Lin, Y.Y. J. Environ. Sci. 2009, 21, 575580

14. Kim, E. H.; Yim, S. B.; Jung, H. C.; Lee, E. J. J. Hazard. Mater. 2006, 136, 690-697

15. American Public Health Association, American Water Works Association and Water Environment Federation. Standard Methods for the Examination of Water and Wastewater. American Standard, 2006.

16. Mañas, A.; Biscans, B.; Spérandio, M. Water. Res.2011, 45, 3776-3786

17. De-Bashan, L. E.; Bashan, Y. Water. Res. 2004, 38, 4222-4246

18. Box, G. E.; Wilson, K. B. J. R. Statist.Soc.1951, 13, 1-45 